\title{
Analisis pengaruh panjang pipa tembaga kondensor terhadap volume hasil minyak pada alat pirolisis
}

\author{
Yusuf Arisandi ${ }^{\star}$, Mochamad Arif Irfa' $i^{2}$, Basuki ${ }^{3}$ \\ Program Studi Teknik Mesin, Fakultas Teknik, Universitas Hasyim Asy'ari ${ }^{1,2,3}$ \\ JI. Irian Jaya 55 Tebuireng Tromol Pos IX Jombang Jatim Telp. (0321) 861719 (Hunting), \\ 864206, 851396, 874685 Fax. 874684 \\ Corresponding author. Sandiari3455@gmail.com
}

\begin{abstract}
A condenser is a tool that functions as a coolant for a pyrolyzer that uses LDPE-type plastik waste as the base material. The pipes contained in the condenser are made of copper and brass which are spiral or twisted. In this study using a condenser with $\emptyset 8 \mathrm{~mm}$ copper pipe with a length of $1000 \mathrm{~mm}$ and $2000 \mathrm{~mm}$. This study used experimental research methods to test the condenser against the oil yield. The results obtained from testing the condenser with $1 \mathrm{~kg}$ of LDPE plastik were the highest volume of oil in copper pipe $\emptyset 8 \mathrm{~mm}$ with a length of $2000 \mathrm{~mm}$ yielding $400 \mathrm{ml}$. This study uses 2-way ANOVA data processing, the results obtained from the volume of oil are the sig. 0.000 indicates that there is a significant effect on the yield of oil volume, this indicates that there is a significant effect on the volume of oil.
\end{abstract}

Keywords: Oil Yield, Condenser, Pyrolysis, Copper Pipe Length, LDPE Plastik.

\begin{abstract}
Abstrak
Kondensor merupakan suatu alat yang berfungsi sebagai pendingin pada alat pirolisator yang menggunakan bahan dasar limbah plastik bertipe LDPE. Pipa yang terdapat dalam kondensor berbahan dari tembaga dan kuningan yang berbentuk spiral atau melilit. Pada penelitian ini menggunakan kondensor dengan pipa tembaga $\varnothing 8 \mathrm{~mm}$ dengan panjang 1000 $\mathrm{mm}$ dan $2000 \mathrm{~mm}$. Penelitian ini menggunnakan metode penelitian eksperimental untuk menguji kondensor terhadap hasil minyak, Hasil yang diperoleh dari pengujian kondensor dengan $1 \mathrm{~kg}$ plastik jenis LDPE yaitu volume minyak tertinggi pada pipa tembaga $\varnothing 8 \mathrm{~mm}$ dengan panjang $2000 \mathrm{~mm}$ menghasilkan $400 \mathrm{ml}$. Penelitian ini menggunakan pengolahan data ANOVA 2 jalur, hasil yang diperoleh dari hasil volume minyak yaitu nilai sig. 0.000 menunjukkan terdapat pengaruh signifikan terhadap hasil volume minyak, hal ini menunjukkan terdapat pengaruh signifikan terhadap volume minyak.
\end{abstract}

Kata kunci: Hasil Minyak, Kondensor, Pirolisis, Panjang Pipa Tembaga, Plastik LDPE.

\section{Pendahuluan}

Limbah plastik merupakan salah satu pencemaran lingkungan hidup di Indonesia dan di dunia, karena plastik sebagai produk serbaguna yang kegunaannya cukup mudah sehingga seluruh dunia berambisi untuk memproduksi lebih banyak produk dengan bahan dasar plastik. Akan tetapi tanpa sadar dalam penggunaannya plastik sangat tidak ramah lingkungan, yang bahkan dapat merusak lingkungan. Dalam hal ini penggunaan produk dengan bahan dasar plastik harus diimbangi dengan penanggulangan dari dampak negatif yang dihasilkan oleh plastik [2].

Metode recycle adalah metode daur ulang yang dapat diterapkan pada sampah plastik, seperti pembuatan aksesoris dari sampah plastik, maupun menggunakannya sebagai energi alternatif. Metode lainnya yaitu dengan insinerasi atau biasa disebut dengan pembakaran terbuka diudara, akan tetapi metode ini menghasilkan emisi 
berupa gas beracun yang sangat berbahaya bagi Kesehatan [5].

Pirolisis merupakan salah satu cara pengolahan limbah plastik yang dinilai cukup prospektif, dan hasil yang diperoleh dari proses pirolisis juga berpotensi sebagai bahan bakar alternatif, karena prosesnya membutuhkan pemanasan dengan suhu yang tinggi sehingga dapat mengubah limbah plastik menjadi bahan bakar cair alternatif [9].

Proses pengolahan dengan metode pirolisis menggunakan alat yang disebut dengan pirolisator. Alat ini berfungsi untuk memproduksi uap cair, dengan prinsip kerja dekomposisi atau menguraikan bahan baku yang berpotensi menghasilkan uap cair. Pada alat pirolisator terdapat proses pendingin yang berfungsi untuk mengubah uap menjadi bahan bakar minyak, yang disebut dengan kondensor. Kondensor ini berupa pipa tembaga AC, yang nantinya akan dialiri uap hasil pembakaran yang kemudian akan diubah menjadi cairan bahan bakar alternatif [7].

Desain yang dipilih akan banyak memberikan pengaruh terhadap hasil kondensasi, karena bentuk geometri dari suatu kondensor berpengaruh terhadap proses transfer panas yang terjadi di dalamnya. Nilai konduktivitas bahan suatu kondensor memberikan pengaruh besar terhadap efektivitas proses transfer panas yang terjadi di dalam kondensor, karena semakin tinggi nilai konduktivitas bahan maka proses transfer panasnya akan semakin baik dan efisiensi akan meningkat [6].

Bentuk geometri pada pipa kondensor dapat berpengaruh terhadap proses maupun hasil dari pirolisis minyak. Dalam hal ini, bentuk geometri yang divariasi oleh peneliti berupa panjang pipa kondensor dan diameter pipa kondensor. Pengaruh yang dihasilkan oleh variasi bentuk geometri pipa kondensor berupa adanya perbedaan laju perpindahan panas menyeluruh dan volume minyak plastik [4].

\section{Tinjauan Pustaka}

Pirolisis merupakan suatu teknik pengembangan karbonisasi (zat organik menjadi residu) kayu ataupun bahan serupa yang saat ini telah banyak berkembang dimasyarakat. Pada teknik karbonisasi biasanya menggunakan pembakaran kayu maupun bahan bakar lainya, yang dilakukan dalam suatu drum, tungku, maupun lubang yang ditutup sehingga ruang tersebut kedap dari udara, dimana pembakaran tersebut menggunakan suhu tinggi dan dalam waktu tertentu. Uap yang dihasilkan dari proses pirolisis tidak dilepaskan ke udara, akan tetapi dikondensasikan sehingga akan membentuk aliran hitam yang disebut dengan asap air atau cairan, pirolygneous liquor/crud [1].

Limbah adalah material sisa yang tidak lagi terpakai yang berasal dari suatu proses produksi baik industri maupun domestik (rumah tangga), yang terdapat pada suatu tempat tertentu dan tidak diinginkan oleh lingkungan atau alam karena tidak lagi mempunyai nilai ekonomis. Limbah dapat digolongkan menjadi limbah cair, limbah padat, limbah gas, dan partikel serta limbah B3 (bahan berbahaya dan beracun) [5].

Plastik merupakan salah satu jenis makromolekul yang dibuat dengan teknik polimerisasi. Polimerisasi merupakan suatu proses penggabungan lebih dari satu molekul sederhana (manomer) dengan melewati proses kimia yang nantinya akan menjadi molekul besar (makromolekul atau polimer). Unsur penyusutan utama yang terkandung dalam plastik berupa karbon dan hidrogen. Secara umum, kelebihan plastik dibanding dengan material lain, antara lain bahannya kuat, ringan, lebih fleksibel, tahan korosi, tidak mudah pecah, mudah dibentuk dan diberi warna, serta merupakan isolator panas dan listrik yang baik [8].

Bahan bakar merupakan segala sesuatu yang dapat diubah menjadi bentuk energi. Umumnya bahan bakar mengandung energi panas yang dapat dilepas dan dapat dimanipulasi. 
Penggunaan bahan bakar yaitu melalui proses pembakaran atau disebut dengan reaksi redoks, dimana bahan bakar tersebut akan melepas panas melalui reaksi oksigen diudara [1].

Kondensor adalah salah satu alat yang berfungsi sebagai penukar panas jenis rekuperator. Rekuperator sendiri didefinisikan sebagai alat perpindahan panas yang cara kerjanya adalah dimana terdapat suatu fluida yang terpisah dari fluida lainnya dengan pemisah yang berupa dinding atau sekat yang dilalui oleh panas [3].

Kondensor mempunyai fungsi untuk tempat kondensasi refrigan ketika dalam proses desorpsi, hal ini bertujuan untuk membuang kalor dan mengubah bentuk bahan pendingin yang awalnya berupa gas menjadi cair [3].

\section{Metode Penelitian}

Jenis penelitian yang penulis gunakan adalah penelitian kuantitatif dengan metode eksperimental dengan variabel bebasnya panjang pipa tembaga ac, $1000 \mathrm{~mm}$ dan $2000 \mathrm{~mm}$. Variabel terikatnya adalah volume minyak yang diperoleh dari proses pirolisator. Sedangkan variabel kontrolnya yaitu jenis plastik yang digunakan plastik LDPE, berat plastik $1 \mathrm{~kg}$, temperatur 300 ${ }^{\circ} \mathrm{C}$, diameter pipa tembaga $\varnothing 8 \mathrm{~mm}$ dan alat pirolisis. Hasil yang diperoleh dari pengujian kemudian dianalisis dan mendapatkan kesimpulan. Berikut ini adalah flowchart penelitian yang dapat dilihat pada Gambar 1 sebagai berikut:

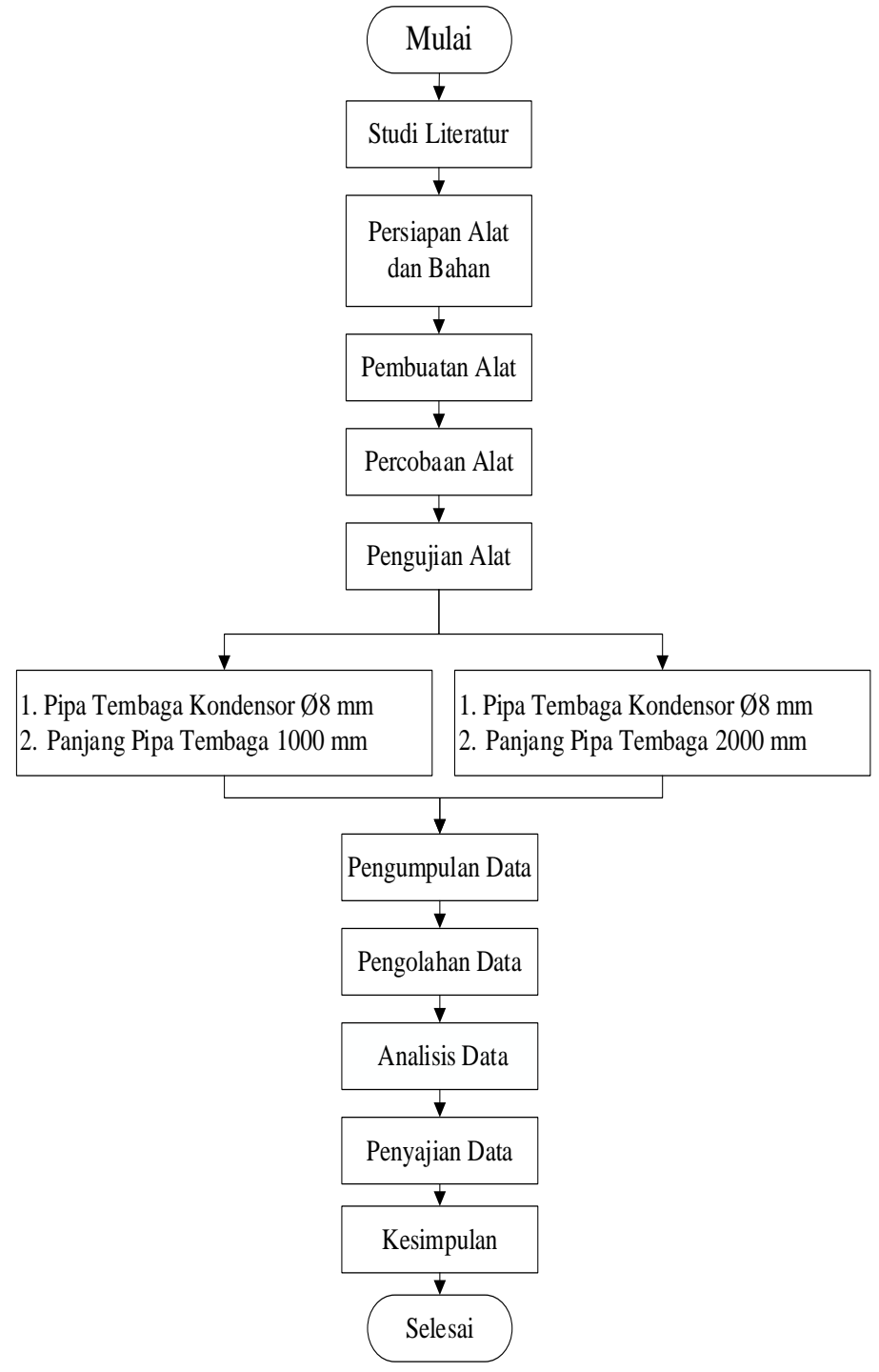

Gambar 1. Flowchart Penelitian.

Variabel yang di gunakan dalam penelitian ini adalah sebagai berikut :

1. Variabel bebas

Variabel bebas merupakan variabel yang mempengaruhi dan yang menjadi sebab perubahanya variabel terikat. Pada penelitian ini varibel bebasnya adalah variasi kondensor $\varnothing 8 \mathrm{~mm}$ dengan panjang pipa tembaga $2000 \mathrm{~mm}$. Kondensor $\varnothing 8 \mathrm{~mm}$ dengan panjang pipa tembaga $1000 \mathrm{~mm}$.

2. Variabel terikat

Variabel terikat yaitu suatu faktor yang dapat diobservasikan dan dapat diukur dengan tujuan untuk mengetahui pengaruh dari variabel bebas tesebut. Pada penelitian ini variabel terikat 
adalah volume minyak yang diperoleh dari proses pirolisis.

3. Variabel kontrol

Variabel kontrol ialah bentuk variabel yang dapat dikendalikan dan juga bisa mempengaruhi variabel bebas terhadap varibel terikat, dan tidak dapat dipengaruhi oleh faktor dari luar yang tidak diteliti. Variabel kontrol dalam penelitian ini yaitu jenis plastik yang digunakan plastik $L D P E$, berat plastik 1 $\mathrm{kg}$, temperatur $300{ }^{\circ} \mathrm{C}$, diameter pipa tembaga $\emptyset 8 \mathrm{~mm}$ dan alat pirolisis.

Kajian yang telah dipelajari oleh peneliti mengenai perancangan kondensor hingga analisis dalam pengujian maupun pengolahan data nantinya akan menghasilkan data yang akurat dan valid dengan dibantu menggunakan software SPSS. Perancangan kondensor terdiri dari beberapa tahap, tahap awal yaitu dengan menentukan desain alat dan juga persiapan alat serta bahan yang akan digunakan dalam penelitian. Setelah alat dan bahan telah dipersiapkan kemudian akan dirancang bagian kondensor berupa tabung besi dan pipa tembaga AC. Rancangan kondensor selanjutnya yaitu membuat lilitan spiral pada pipa tembaga AC dengan ketebalan $2 \mathrm{~mm}$. Tahap berikutnya yaitu dengan menggabungkan antara komponen kondensor, yaitu pada komponen tabung besi dan pipa tembaga $\mathrm{AC}$, kemudian dari kedua ujung tabung besi ditutup dengan lepengan besi

Langkah yang diambil setelah produk kondensor yang telah selesai dirancang adalah menguji kondensor dengan cara membakar plastik jenis LDPE pada tabung reactor dengan massa plastik $1 \mathrm{~kg}$, dengan suhu $300{ }^{\circ} \mathrm{C}$, serta lama waktu pembakaran 60 menit. Selanjutnya uap dari pembakaran tersebut kemudian akan melewati tabung kondensor dan didalam kondensor tersebut terjadi proses kondensasi atau perubahan zat uap menjadi zat cair (bahan bakar alternatif). Dalam pengujian kompor biomassa, hal yang menjadi acuan untuk mendapatkan data antara lain dengan menggunakan alat pengukur suhu termometer untuk mengukur suhu air dan stopwacth untuk mengukur waktu yang ditempuh dalam proses pirolisator yaitu 60 menit. Setelah memperoleh hasil kemudian dilakukan pengolahan data, analisis data dan penyajian data yang kemudian data tersebut dapat disimpulkan sesuai dengan hasil yang di dapat saat penelitan.

Dalam memperoleh data yang diinginkan pada penelitian ini, peneliti melakukan pengujian dengan cara:

1. Mengukur volume minyak yang dihasilkan

Dalam penelitian ini analisis yang digunakan adalah analisis eksperimen, yaitu dengan $\varnothing 8 \mathrm{~mm}$ dengan panjang 2000 $\mathrm{mm}$. dan $\varnothing 8 \mathrm{~mm}$ dengan panjang 1000 mm. terhadap volume minyak yang diperoleh dari tiap kondensor.

\section{Hasil dan Pembahasan}

\section{Pengujian kondensor}

Kondensor yang telah selesai dirancang nantinya akan diuji berdasarkan fungsinya maupun diuji berdasarkan dari variasi pipa tembaganya. Pengujian berdasarkan fungsi merupakan pengujian terhadap kinerja kondensor untuk mengetahui kondensor tersebut bekerja dengan baik. Sedangkan pengujian kondensor berdasarkan variasi pipa tembaga adalah untuk mengetahui volume hasil minyak yang diperoleh dari masingmasing pipa tembaga yang digunakan dalam penelitian ini.

Adapun langkah-langkah yang dilakukan pada proses pengujian kinerja kondensor antara lain:

1. Pemotongan bahan yang akan digunakan dalam pengujian. 


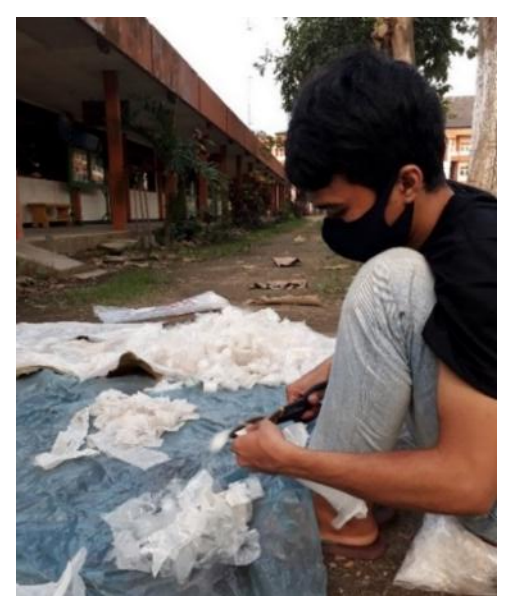

Gambar 2. Proses Pemotongan Plastik

2. Jumlah plastik yang digunakan dalam proses pengujian yaitu $1 \mathrm{~kg}$.

3. Memasukkan bahan bakar ke dalam tabung reaktor melalui lubang bagian atas tabung reaktor.

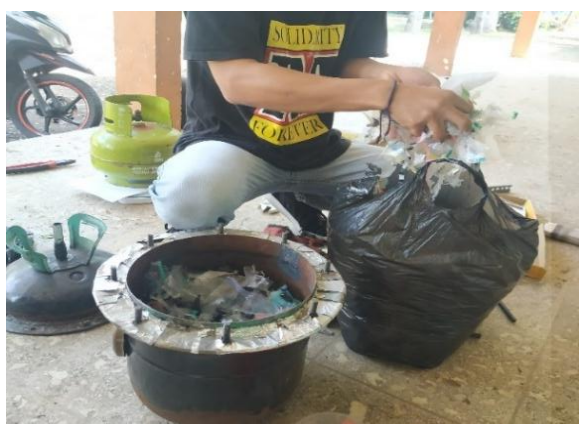

Gambar 3. Bahan bakar didalam Tabung Reaktor

4. Nyalakan kompor untuk proses pengujian selama 1 jam dengan suhu pembakaran $300^{\circ} \mathrm{C}$.

5. Selama proses pengujian berjalan dilakukan pengecekan suhu air pendingin, suhu uap masuk dan suhu uap keluar.

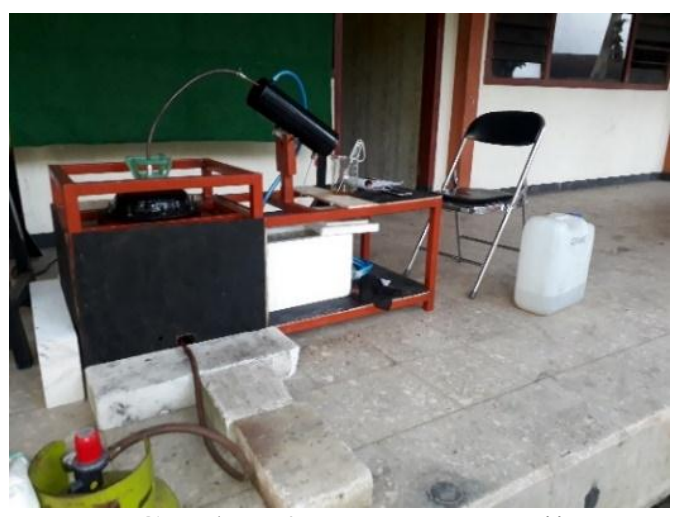

Gambar 4. Proses Pengujian
Berdasarkan tahapan pada proses pengujian kinerja kondensor, jika telah didapatkan nyala api yang merata maka dapat disimpulkan bahwa kompor biomassa tersebut dapat bekerja dengan baik.

\section{Volume hasil minyak yang diperoleh}

Hasil dari pengujian alat pirolisator dengan variasi diameter pipa $\varnothing 8 \mathrm{~mm}$ dengan panjang pipa tembaga $2000 \mathrm{~mm}$ dan $\varnothing 8 \mathrm{~mm}$ dengan panjang pipa tembaga $1000 \mathrm{~mm}$ disajikan pada tabel berikut ini.

Tabel 1.Hasil Pengujian Tabung Kondensor Variasi Pipa Tembaga $\varnothing 8 \mathrm{~mm}$ dengan Panjang Pipa Tembaga $2000 \mathrm{~mm}$

\begin{tabular}{cccc}
\hline $\begin{array}{c}\text { Pengujian } \\
\text { Ke }-\end{array}$ & $\begin{array}{c}\text { Suhu } \\
\text { Uap } \\
\text { Masuk } \\
\left({ }^{\circ} \mathrm{C}\right)\end{array}$ & $\begin{array}{c}\text { Suhu } \\
\text { Uap } \\
\text { Keluar } \\
\left({ }^{\circ} \mathrm{C}\right)\end{array}$ & $\begin{array}{c}\text { Voliume } \\
\text { Minyak } \\
(\mathrm{ml})\end{array}$ \\
\hline 1 & 151,5 & 25,8 & 410 \\
\hline 2 & 109,8 & 24,6 & 410 \\
\hline 3 & 100,9 & 25,8 & 380 \\
\hline Rata-rata & 120,73 & 25,40 & 400 \\
\hline
\end{tabular}

Pada Tabel 1, dapat dijelaskan dengan data yang diperoleh dari pengujian yang dilakukan pengulangan $3 \mathrm{kali}$, setelah itu diambil nilai rata-ratanya. Pertama plastik dipanasi pada suhu $300{ }^{\circ} \mathrm{C}$ suhu ini digunakan pada semua pengujian tersebut. Pada pengujian yang pertama menghasilkan suhu uap plastik $151,5{ }^{\circ} \mathrm{C}$ masuk pada kondensor, kemudian didalam kondensor dialiri air pendingin yang masuk ke dalam kondensor akan menjadi cair (minyak) dengan suhu uap keluar $25,8{ }^{\circ} \mathrm{C}$, serta volume minyak yang dihasilkan yaitu 410 $\mathrm{ml}$.

Selanjutnya pengujian yang kedua didapatkan nilai suhu uap plastik masuk $109,8{ }^{\circ} \mathrm{C}$, suhu uap plastik keluar $24,6{ }^{\circ} \mathrm{C}$, serta volume minyak yang dihasilkan yaitu $410 \mathrm{ml}$. Kemudian pengujian yang ketiga didapatkan nilai suhu uap plastik masuk $100,9^{\circ} \mathrm{C}$, suhu uap plastik keluar $25,8^{\circ} \mathrm{C}$, serta volume minyak yang dihasilkan yaitu $380 \mathrm{ml}$. 
Tabel 2. Hasil Pengujian Tabung Kondensor Variasi Pipa Tembaga $\emptyset 8 \mathrm{~mm}$ dengan Panjang Pipa Tembaga $1000 \mathrm{~mm}$

\begin{tabular}{cccc}
\hline $\begin{array}{c}\text { Pengujian } \\
\text { Ke }-\end{array}$ & $\begin{array}{c}\text { Suhu } \\
\text { Uap } \\
\text { Masuk } \\
\left({ }^{\circ} \mathrm{C}\right)\end{array}$ & $\begin{array}{c}\text { Suhu } \\
\text { Uap } \\
\text { Keluar } \\
\left({ }^{\circ} \mathrm{C}\right)\end{array}$ & $\begin{array}{c}\text { Volume } \\
\text { Minyak } \\
(\mathrm{ml})\end{array}$ \\
\hline 1 & 92,8 & 28,5 & 78 \\
\hline 2 & 95,6 & 26,9 & 76 \\
\hline 3 & 93,5 & 28,4 & 78 \\
\hline Rata-rata & 93,97 & 27,93 & 77,33 \\
\hline
\end{tabular}

Dari tabel 2, dapat dijelaskan dengan data yang diperoleh dari pengujian yang dilakukan pengulangan 3 kali, setelah itu diambil nilai rata-ratanya. Pertama plastik dipanasi pada suhu $300{ }^{\circ} \mathrm{C}$ suhu ini digunakan pada semua pengujian tersebut. Pada pengujian yang pertama menghasilkan suhu uap plastik $92,8{ }^{\circ} \mathrm{C}$ masuk pada kondensor, kemudian didalam kondensor dialiri air pendingin yang masuk kedalam kondensor akan menjadi cair (minyak) dengan suhu uap keluar $28,5{ }^{\circ} \mathrm{C}$, serta volume minyak yang dihasilkan yaitu 78 $\mathrm{ml}$.

Selanjutnya pengujian yang kedua didapatkan nilai suhu uap plastik masuk 95,6 ${ }^{\circ} \mathrm{C}$, suhu uap plastik keluar $26,9{ }^{\circ} \mathrm{C}$, serta volume minyak yang dihasilkan yaitu $76 \mathrm{ml}$. Kemudian pengujian yang ketiga didaptkan nilai suhu uap plastik masuk 93,5 ${ }^{\circ} \mathrm{C}$, suhu uap plastik keluar $28,4{ }^{\circ} \mathrm{C}$, serta volume minyak yang dihasilkan yaitu 78 $\mathrm{ml}$.

\section{Kesimpulan}

Berdasarkan pembahasan di atas, maka dapat ditarik kesimpulan yaitu pengujian kondensor pada alat pirolisis menggunakan bahan plastik jenis LDPE dengan massa $1 \mathrm{~kg}$, serta lama waktu pembakaran 60 menit, dengan menggunakan suhu tetap yaitu $300{ }^{\circ} \mathrm{C}$. Sehingga didapatkan volume minyak tertinggi dengan rata-rata $400 \mathrm{ml}$ pada kondensor $\varnothing 8 \mathrm{~mm}$ dengan panjang pipa tembaga $2000 \mathrm{~mm}$. Sedangkan pada kondensor $\varnothing 8 \mathrm{~mm}$ dengan panjang pipa tembaga $1000 \mathrm{~mm}$ menghasilkan volume minyak rata-rata $77,33 \mathrm{ml}$.

\section{Referensi}

[1] Hendradinata, Beta Akui, Ozkar Firdausi Homzah., 2017. Pengaruh Variasi Panjang dan Diameter Pipa Kapiler Terhadap COP Pada Trainer Sistem Pendingin Dasar. Palembang: Jurnal Teknik Mesin Universitas Tridinanti Palembang.

[2] Jainal Arifin, Sobar Ihsan. 2018. Analisis Perancangan Limbah Plastik Sampah Polythylene Terephthalate untuk Menghasilkan Bahan Bakar Alternatif. Kalimantan: Jurnal Teknik Mesin Universitas Islam Kalimantan.

[3] Kreith, Frank. 1991. Prinsip - Prinsip Perpindahan Panas. Jakarta: Erlangga

[4] Mafruddin. 2017. Pengaruh Geometri Pipa Kondensor Terhadap Perpindahan Panas Pada Destilasi Minyak Plastik. Lampung: Jurnal Teknik Mesin Universitas Muhammadiyah Metro.

[5] Mandala, W.W., Cahyono, S.M., Ma'arif, S., Sukarjo, B.H., Wardoyo. 2016. Pengaruh Suhu terhadap Rendemen dan Nilai Kalor Minyak Hasil Pirolisis Sampah Plasrtik.

[6] Mokhtar, Ali. 2018. Perancangan Pirolisis Untuk Membuat Bahan Bakar Cair Dari Limbah Plastik Kapasitas 10 KG. Malang: Jurnal Teknik Mesin Universitas Muhammadiyah.

[7] Prawijaya, Anton. 2015. Performansi Pirolisator dengan Dua Tahap Kondensasi untuk Pembuatan Asap Cair dari Tempurung Kelapa. Banda Aceh: Jurnal Fakultas Pertanian Universitas Syiah Kuala. 
[8] Surono, Untoro Budi. 2013. Berbagai Metode Konversi Sampah Plastik Menjadi Bahan Bakar Minyak. Yogyakarta: Jurnal Teknik Mesin Universitas Janabara.

[9] Wicaksono, Hendri Dwi. 2018. Investigasi Karakteristik Bahan Bakar Cair Hasil Produk Pyrolisis Jenis Plastik PET dan PP. Kediri: Jurnal Simki Techsain Universitas Nusantara PGRI Kediri. 